\title{
Feasibility Study on Installation of Rooftop Photovoltaic System in Complied with Thailand Energy Building Code
}

\author{
Pathomthat Chiradeja ${ }^{1}$, and Atthapol Ngaopitakkul ${ }^{2}$ \\ ${ }^{1}$ Faculty of Engineering, Srinakharinwirot Universit, Bangkok, Thailand \\ ${ }^{2}$ Faculty of Engineering, King Mongkut's Institute of Technology Ladkrabang, Bangkok, Thailand
}

\begin{abstract}
Renewable energy especially solar energy has become a significant part in electrical power generation with its advantage in the environmentally friendly and current trend of decrease in installation cost. The photovoltaic (PV) system on a rooftop is one of the power generating system based on renewable energy that can fit building to utilize space efficiently. This paper is analyzing the feasibility of installing a solar PV rooftop on the building using a case study building located in Bangkok, Thailand. The performance will be evaluated in term of both energy and economic perspective. The comparison with Thailand building energy code also been done to show that overall energy consumption with PV system complies with the law. The result has shown that with rooftop photovoltaic system installation, annual energy consumption in the building can be reduced significantly and it can achieve feasibility in term of economic perspective.
\end{abstract}

\section{Introduction}

Renewable energy especially energy from solar will be one of the primary sources of energy in the future. From the energy statistic and its trends in the future, Thailand government has the focus to reduce energy intensity (EI) by $20 \%$ or 30,000 ktoe compare to business-as-usual (BAU) case in 2036 according to Energy Efficiency Development Plan (EEDP) [1]. In order to achieve this target, the government also set up the law "The Energy Conservation Promotion Act 1992" that act as the standard for Building Energy Code (BEC) to improved energy efficiency in building. The law can be summarized that both newly built and retrofitted building that has a usage area more than 2,000 square meters must comply with this energy code [2]. Six systems in the building under consideration in this code consist of Envelope, Lighting, heating, ventilation, and air conditioning (HVAC), renewable energy, hot water system, and overall energy consumption.

In the case of photovoltaic system, the BEC standard has specified that building within standard value must have overall energy consumption less than overall energy consumption of reference building with the same total area. The reference value has been set by standard value. The power generates from solar PV rooftop can be used to subtract from overall energy consumption in order to create an incentive for building's owner to invest in renewable energy.

Literature review in the field of energy efficiency improvement in building and application of the photovoltaic system in both past research and case studies has been done to determine the feasibility to implement. The study on the potential of solar PV rooftop in the urban area of Mumbai, India reveals that this system has potential with estimated generating capacity at $2190 \mathrm{MW}$ and can be helping to reduce peak demand [3]. The simulation of the grid-connected solar PV rooftop system on the small residential building also been discussed [4]. The study on the performance of a rooftop PV system using a crystalline type panel under weather condition has been present [5]. In the case of Thailand, the current situation and challenge of a solar PV rooftop system have been discussed. The primary factor that can affect investor decision such as limit domestic technology in the manufacturing sector, public awareness, and decrease in government subsidy has been analyzed [6]. In term of environmental, the Life Cycle Assessment (LCA) on Bangkok, solar PV rooftop was shown that the system had achieved net $\mathrm{CO} 2$ reduction [7]. Finally, for Thailand feed-in tariff (FiT) support, it still lacking, which tax incentive and economic stimulation programs can further attract an investor [8].

From the literature review, it can be seen that solar rooftop system can be installed as an alternative electrical energy source from distribution grid in order to reduce energy cost and whole building energy consumption according to BEC standard. So, this paper aims to present a feasibility analysis of the installation of a solar rooftop in term of energy performance and economic perspective using a case study building located in Bangkok, Thailand. So, this paper proposed the studies on the photovoltaic rooftop system in building using a case study building located in Bangkok, Thailand. The comparison with Thailand building energy code will be made to evaluate building with the BEC in term of 
energy usage before and after the installation of a rooftop PV system. The analysis of energy performance and feasibility of the project in term of economic perspective also been done. This result can be used as a guideline and case study to promote the investment in solar PV rooftop in a building.

\section{Case study building and location}

The eight floors apartment building located in Bangkok, Thailand has been used as a case study building in this research. The overview of the building and floor plan of the rooftop using in the case study is shown in Fig. 1 and 2 respectively. In Fig. 2 also shown the layout of rooftop PV system installation. This building has an estimated total area on the rooftop around 2,400 square meters.

The factor that significantly affected the performance of the rooftop PV system is weather condition. The weather data in Bangkok from the Thai Meteorological Department in term of monthly average temperature and solar irradiance is shown in Fig. 3 and detail data that include relative humidity, precipitation, and wind speed is shown in Table 1.

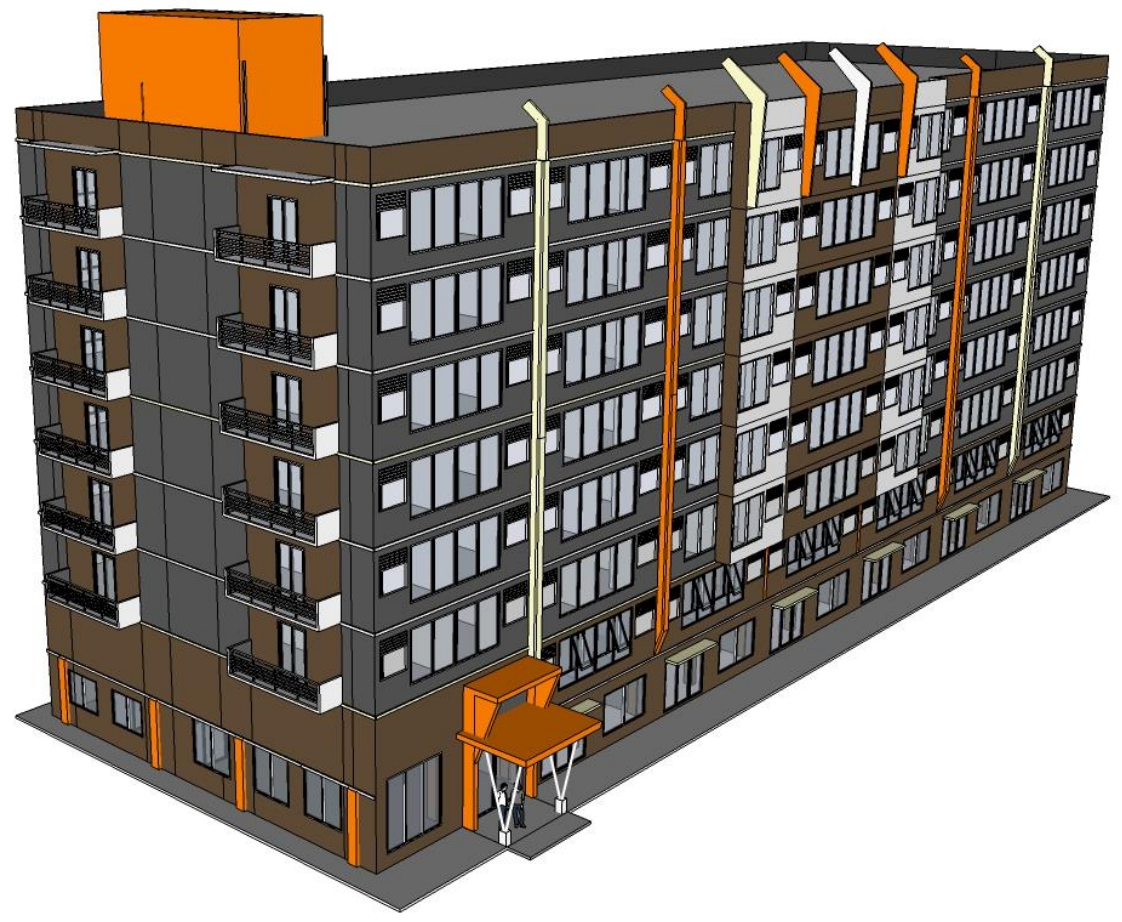

Fig. 1. Overview of case study building.

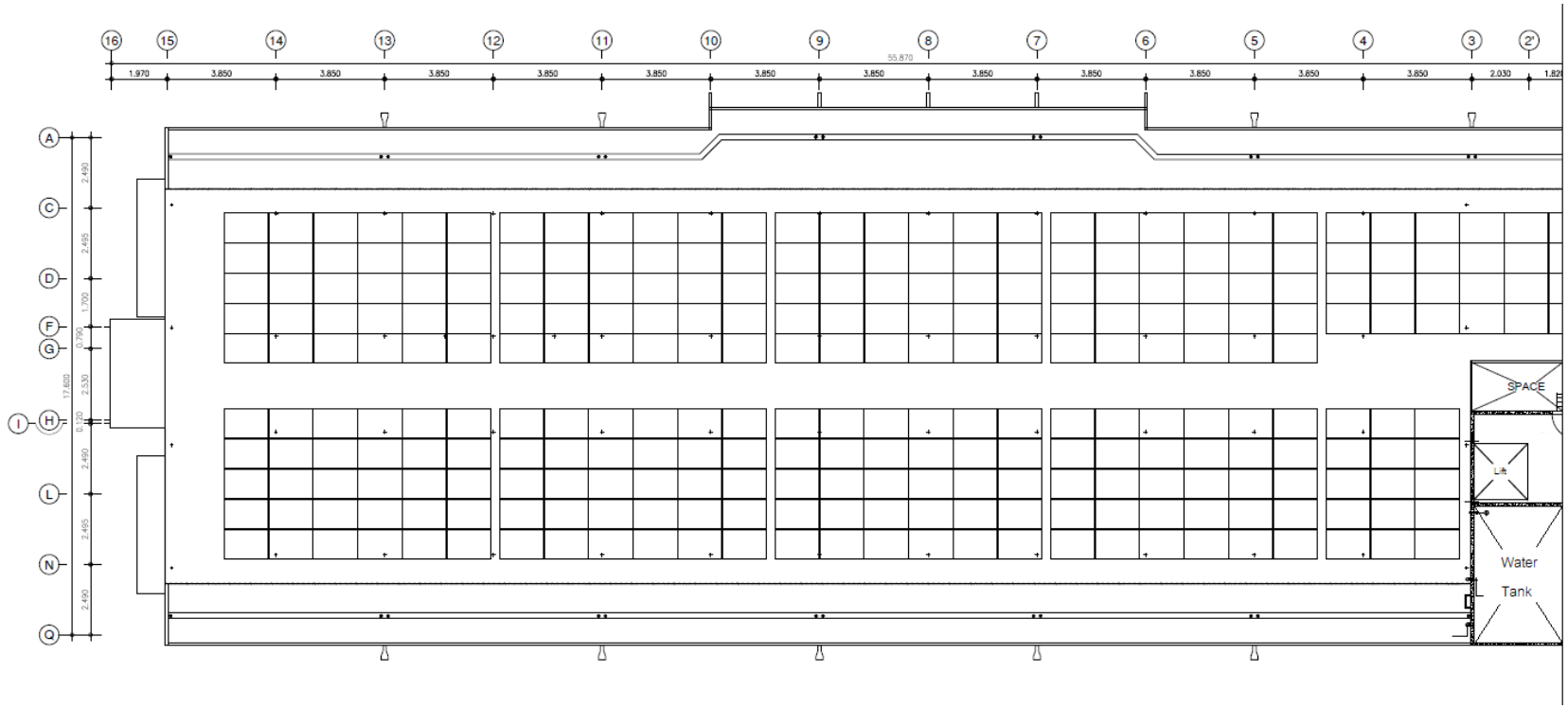

Fig. 2. Layout of case study building rooftop. 


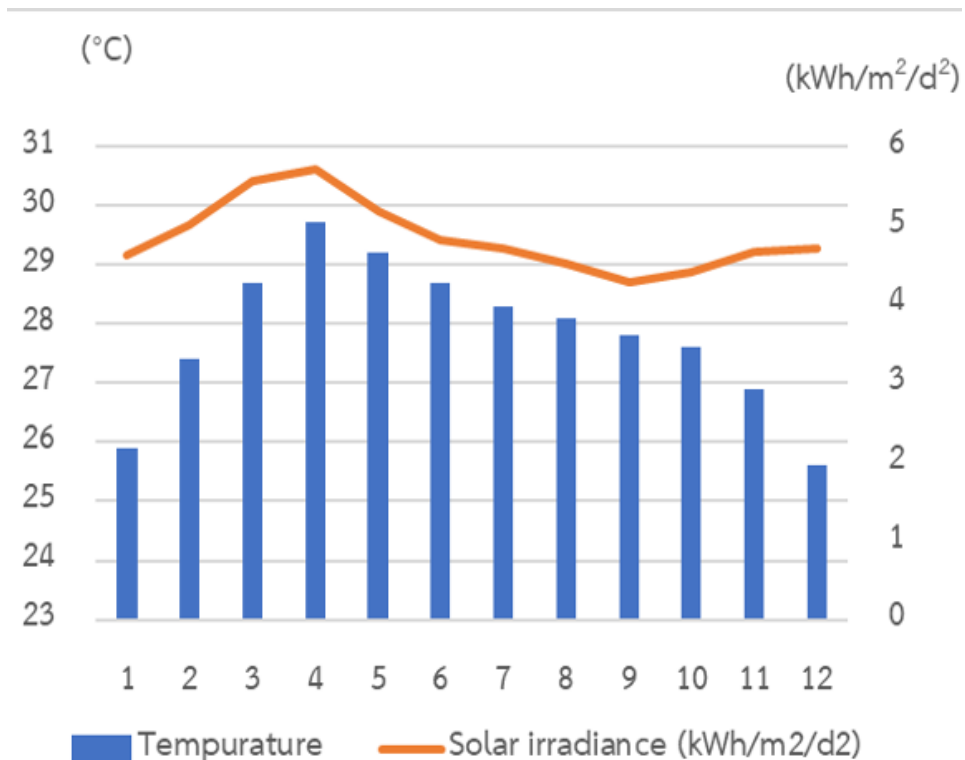

Fig. 3. Solar irradiance and Temperature in Bangkok.

Table 1. Weather Data in Bangkok Area

\begin{tabular}{|c|c|c|c|c|c|}
\hline Month & Temperature & $\begin{array}{c}\text { Relative Humidity } \\
\text { (\%) }\end{array}$ & $\begin{array}{c}\text { Precipitation } \\
\text { (mm) }\end{array}$ & $\begin{array}{c}\text { Solar irradiance } \\
\left(\mathbf{k W h} / \mathrm{m}^{2} / \mathrm{d}\right)\end{array}$ & Wind Speed $(\mathrm{m} / \mathrm{s})$ \\
\hline January & 25.9 & 68.1 & 11.03 & 4.62 & 1.3 \\
\hline February & 27.4 & 71.4 & 18.03 & 5 & 2 \\
\hline March & 28.7 & 71.8 & 42.21 & 5.56 & 2.5 \\
\hline April & 29.7 & 71.5 & 102.11 & 5.7 & 2.3 \\
\hline May & 29.2 & 74 & 265.69 & 5.18 & 1.9 \\
\hline June & 28.7 & 74 & 257.5 & 4.81 & 1.9 \\
\hline July & 28.3 & 74.1 & 272.85 & 4.7 & 1.8 \\
\hline August & 28.1 & 75 & 292.23 & 4.52 & 1.8 \\
\hline September & 27.8 & 78.8 & 375.66 & 4.27 & 1.3 \\
\hline October & 27.6 & 77.8 & 260.83 & 4.41 & 1 \\
\hline November & 26.9 & 69.5 & 57.85 & 4.66 & 1.2 \\
\hline December & 25.6 & 64.2 & 16.12 & 4.7 & 1.2 \\
\hline Annual Average & 27.8 & 72.5 & $1,972.12$ & 4.84 & 1.7 \\
\hline
\end{tabular}

From the table, the climate on Bangkok area is suitable to installed rooftop PV system with an average annual temperature at 27.8 degree Celsius and solar irradiance $4.84 \mathrm{kWh}$ per square meter per day.

The specification of the photovoltaic panel and other equipment using in the solar rooftop system is shown in Table. 2. The Monocrystalline type photovoltaic panel module with $360 \mathrm{~W}$ power generating capacity per panel has been used due to it provide high efficiency with the same amount of space compared to other types of PV panel. The PV has 16 parallel string with 18 PV panel connected in series connection. The total area of the PV panel installation is 469.64 square meter. Two sets of inverters with $50 \mathrm{~kW}$ capacity each has been used 
separated north and south side of the rooftop. The panel is installed in the south direction with an inclination degree at 15 degrees in order to achieved maximum generating capacity.

Table 2. Specification of Photovoltaic System.

\begin{tabular}{|c|c|}
\hline \multicolumn{2}{|c|}{ Specification } \\
\hline Photovoltaic Panel & Monocrystalline \\
\hline Power Generation per panel & $360 \mathrm{~W}$ \\
\hline Number of Panels & 288 \\
\hline Inverter Capacity & $50,000 \mathrm{~W}$ \\
\hline Number of Inverters & 2 \\
\hline
\end{tabular}

\section{Result}

The performance of a rooftop PV system on a case study will be evaluated in the perspective of both energy performance and economic parameter.

\subsection{Energy performance}

In term of energy performance, Power generated from the rooftop PV system is estimated at 71,708.00 $\mathrm{kWh}$ per year at $15.2 \%$ capacity factor. According to the standard, whole building energy consumption for building with a total area $8,827.28$ square meter is $611,959.10 \mathrm{kWh}$ per year. Before the installation of the solar PV rooftop system, case study building has estimated energy consumption at $652,744.29 \mathrm{kWh}$ per year higher than the standard value. After the installation of the solar PV rooftop system, energy consumption has been reduced to $581,036.29 \mathrm{kWh}$ per year within standard value. The comparison with the BEC standard is shown in Table. 3.

Table 3. Comparison with BEC Standard.

\begin{tabular}{|l|c|}
\hline \multicolumn{2}{|c|}{ Whole Building Energy Consumption (kWh/yrs) } \\
\hline Reference Building & $611,959.10$ \\
\hline Evaluated Building (Before PV installation) & $652,744.29$ \\
\hline Evaluated Building (After PV installation) & $581,036.29$ \\
\hline Energy from PV system & $71,708.00$ \\
\hline
\end{tabular}

\subsection{Economic parameter}

For analysis of economic parameter in this research, the Discounted payback period and internal rate return (IRR) that are two significant economic parameters will be used to evaluate the feasibility for building to invest into rooftop PV system. The discounted payback period can be calculated using equation (1) and (2).
Discounted Cash Inflow $=\frac{\text { Actual Cash Inflow }}{(1+i)^{n}}(1)$

$$
\text { Discounted Payback Period }=A+\frac{B}{C}
$$

When

$i \quad$ is Discounted rate.

$n \quad$ is Period of cash flow (years).

$A$ is Negative discounted cumulative cash flow.

$B$ is Discounted cumulative cash flow at the end of the period $\mathrm{A}$.

C is Discounted cash flow during the period after A. (3)

For the IRR value, it can be calculated using equation

$$
I_{0}=\sum_{t=1}^{n} \frac{E S_{t}}{(1+I R R)^{t}}=0
$$

When

$I_{0} \quad$ is Initial investment.

$n \quad$ is Project life (years).

$E S_{t} \quad$ is Annual energy cost saving from year 1 to n.

$I R R$ is Internal rate of return.

The cost of equipment in solar PV rooftop system and installation cost is shown in Table 4. The calculation of the discounted payback period and cash balance in each year is shown in Table 5 .

From the table, it is shown that energy cost reduction is the amount of electrical price that will be saved in case of installed solar PV rooftop. The cost of electrical energy in Thailand is 3.93 bath or 0.118 USD per $\mathrm{kW} / \mathrm{hr}$. The result from the table shown that the discounted payback period is 9.72 years and IRR value is $10.10 \%$ when calculated using a $2.0 \%$ inflation rate according to the forecast of Bank of Thailand.

Table 4. Formatting sections, subsections and subsubsections.

\begin{tabular}{|l|c|}
\hline \multicolumn{2}{|c|}{ Rooftop PV System Cost $\left.\mathbf{( \$}^{\mathbf{a}}\right)$} \\
\hline PV panel & $45,792.00$ \\
\hline Inverter & $9,198.00$ \\
\hline Other equipment & $6,705.30$ \\
\hline Installation cost & $10,000.00$ \\
\hline Total & $71,695.30$ \\
\hline
\end{tabular}


Table 5. Payback Period

\begin{tabular}{|c|c|c|c|c|c|}
\hline Year & $\begin{array}{c}\text { Installation } \\
\text { Cost }\end{array}$ & $\begin{array}{c}\text { Energy Cost } \\
\text { Reduction }\end{array}$ & $\begin{array}{c}\text { Maintenance } \\
\text { Cost }\end{array}$ & $\begin{array}{c}\text { Net Present } \\
\text { Value }\end{array}$ & Balance \\
\hline 0 & $606,748.40$ & 0.00 & 0.00 & $-606,748.40$ & $-606,748.40$ \\
\hline 1 & - & $92,126.91$ & $4,442.75$ & $85,964.86$ & $-520,783.53$ \\
\hline 2 & - & $91,214.77$ & $4,442.75$ & $83,402.51$ & $-437,380.97$ \\
\hline 3 & - & $90,311.65$ & $4,442.75$ & $80,916.14$ & $-356,464.79$ \\
\hline 4 & - & $89,417.48$ & $4,442.75$ & $78,503.29$ & $-277,961.28$ \\
\hline 5 & - & $88,532.15$ & $4,442.75$ & $76,162.34$ & $-201,798.91$ \\
\hline 6 & - & $87,655.60$ & $4,442.75$ & $73,890.62$ & $-127,908.28$ \\
\hline 7 & - & $86,787.72$ & $4,442.75$ & $71,686.28$ & $-56,222.08$ \\
\hline 8 & - & $85,928.44$ & $4,442.75$ & $69,547.25$ & $13,325.22$ \\
\hline 9 & - & $85,077.66$ & $4,442.75$ & $67,471.68$ & $80,796.90$ \\
\hline
\end{tabular}

\section{Conclusion}

This research aims to present the feasibility to installing a solar PV rooftop system in term of energy saving and economic perspective by using a case study from an actual building located in Thailand. The result shows that in term of energy perspective, solar PV rooftop can generate power at an average annual rate of $71,708 \mathrm{kWh}$ per year. When compared with the BEC standard, the solar PV rooftop system can calculate as a reduction for overall building consumption. The building with photovoltaic installation can achieve significant energy reduction compare to reference building and can be in complying with the standard. In term of economic perspective, the solar PV rooftop system has an attractive economic parameter with 9.72 years discounted payback period and $10.10 \%$ IRR value. This result also shows that the solar PV rooftop system has the potential for building an application that can save the owner from energy cost and help the building complied with the law.

\section{Acknowledgement}

The authors wish to gratefully acknowledge financial support for this research from Faculty of Engineering, King Mongkut's Institute of Technology Ladkrabang Research fund, Thailand.

\section{References}

1. Department of Alternative Energy Development and Efficiency, Ministry of Energy "Thailand 20-Year
Energy Efficiency Development Plan (2011 - 2030)", 2011

2. The Energy Conservation Promotion Act B.E. 2535, 1992

3. Rhythm Singh, Rangan Banerjee, "Estimation of rooftop solar photovoltaic potential of a city," Solar Energy, Volume 115, 2015, Pages 589-602.

4. Chandrakant Dondariya, Deepak Porwal, Anshul Awasthi, Akash Kumar Shukla, K. Sudhakar, Murali Manohar S.R., Amit Bhimte, "Performance simulation of grid-connected rooftop solar PV system for small households: A case study of Ujjain, India,” Energy Reports, Volume 4, 2018, Pages 546553.

5. K. Atluri, S. M. Hananya and B. Navothna, "Performance of Rooftop Solar PV System with Crystalline Solar Cells," 2018 National Power Engineering Conference (NPEC), Madurai, 2018, pp. 1-4.

6. Aksornchan Chaianong, Chanathip Pharino, "Outlook and challenges for promoting solar photovoltaic rooftops in Thailand," Renewable and Sustainable Energy Reviews, Volume 48, 2015, Pages 356-372.

7. John Eskew, Meredith Ratledge, Michael Wallace, Shabbir H. Gheewala, Pattana Rakkwamsuk, "An environmental Life Cycle Assessment of rooftop solar in Bangkok, Thailand," Renewable Energy, Volume 123, 2018, Pages 781-792.

8. Sopitsuda Tongsopit, "Thailand's feed-in tariff for residential rooftop solar PV systems: Progress so far," Energy for Sustainable Development, Volume 29, 2015, Pages 127-134. 